\title{
Selye János, \\ a kreativitás és eredetiség nagymestere
}

\author{
Somogyi Árpád dr. \\ Gesellschaft für Natur- und Heilkunde, Berlin, Németország
}

\begin{abstract}
Selye János, a stresszelmélet atyja, a XX. század tudományának óriása volt. Leginkább ismert stresszkutatásain túl, a kísérletes orvostudomány számos más területén is tett jelentős felfedezéseket. Többek között leírt és karakterizált különböző plurikauzális betegségeket. Kulcsfontosságú munkái nagyban hozzájárultak az endokrinológia számos területének fejlődéséhez. Kiemelkedő érdemeket szerzett a szteroidok klasszifikálása és hatásmechanizmusainak felderítése terén végzett munkáival. Különböző sebészeti technikákat és emberi betegségek kórfejlődésének és megelőzésének tanulmányozására alkalmas kísérleti állatmodelleket dolgozott ki. Selye egy múvelt, rendkívül magas intelligenciájú és fegyelmezett ember, eredeti és kreatív tudós, kiváló tanítómester, filozófus, termékeny szerző, csodálatos kommunikátor és legendás szervező volt. Ez utóbbi készségét meggyőzően bizonyította intézetének, a világhírű, a Montreali Egyetemen alapított, Kísérletes Orvostudományi és Sebészeti Intézet felépítésével és évtizedek során mutatott szuverén vezetésével. Orv. Hetil., 2015, 156(35), 1396-1401.
\end{abstract}

Kulcsszavak: Selye, stressz, plurikauzális betegségek, szteroidok

\section{Hans Selye, the grandmaster of creativity and originality}

Hans Selye, the father of the stress concept, was a giant of science of the twentieth century. Beyond his best-known work on stress, he also made several discoveries on various other fields of experimental medicine. He described and characterized various pluricausal diseases. In addition, he made pivotal contributions to the broad field of endocrinology, especially to the classification of steroids and to our better understanding of their mode of action. He developed surgical technics and experimental animal models suitable for studying the pathogenesis and prevention of human diseases. Selye was an extremely well educated, highly intelligent and disciplined individual, an original and creative scientist, an outstanding teacher, a philosopher, a prolific author, a fabulous communicator and a gifted organizer successfully establishing, developing and managing a major academic research institution, the word-famous Institute of Experimental Medicine and Surgery of the University of Montreal.

Keywords: Selye, stress, pluricausal diseases, steroids

Somogyi, Á. [Hans Selye, the grandmaster of creativity and originality]. Orv. Hetil., 2015, 156(35), 1396-1401.

(Beérkezett: 2015. június 4.; elfogadva: 2015. július 2.)

Amikor társszerkesztő kollégáim javaslatára nekikezdtem a közlemény megírásához, úgy gondoltam, hogy ezzel egy aránylag egyszerú feladat teljesítésére vállalkoztam. Hiszen Selye professzor eredetisége és kreativitása az irodalomban megbízhatóan dokumentált. Az viszont, hogy ö ezeknek a tulajdonságainak nagymestere is volt, ugyan általánosan feltételezett, de nagyrészt csak anekdotálisan alátámasztható. Talán ez lehetett az oka annak, hogy rám esett a választás, mivel négyünk közül én ismertem őt a leghosszabb ideig, és azokat is, akik ilyen megélt anekdotákat ismernek.
Selye János tulajdonságai között kreativitása és eredetisége talán a legjobban ismert, elismert, s mondhatjuk leginkább csodált. Ezekhez Selye esetében egy további jellemző talentuma, rendkívül kifinomult kommunikációs képessége társult. Ez utóbbi képességére még később részletesen visszatérek.

A kreativitás és eredetiség fogalma, valamint más aspektusa az évek során számos tudományos, gazdasági, politikai és egyéb intézmény érdeklődését felkeltette. Ennek megfelelően e terület irodalma, az egyes szakirányok igényeinek megfelelően, meglehetősen szerteága- 
zó. A különbségek ellenére nem vitatott, hogy a kreativitás és eredetiség rokon, egyes szerzők szerint részben átfedő fogalmak. „A kreativitás a divergens gondolkodásban nyilvánul meg, amely egy probléma több oldalról való megközelítését teszi lehetővé, illetve olyan elemek összekapcsolását, amelyeket rendszerint egymástól függetlennek, vagy össze nem illőnek tartunk. A divergens gondolkodást segítő feladatoknak egyszerre több helyes megoldása is létezik." Az eredetiség a kreatív egyéniség egyik tulajdonsága [1].

E közleményben kizárólag Selye János kreativitása és eredetisége áll érdeklődésünk középpontjában. Ebben kompetens útmutatással indulhatunk útnak: Selye In Vivo címú könyvének előszavában, Szent-Györgyi Albert Selye eredetiségére célozva átvitt értelemben arról ír, hogy Selye az élet nyelvén tanít bennünket a tudomány szűzföldjére érkezés öröméről és izgalmáról [2].

\section{Találkozásom Selye professzorral}

Selye Jánost nemcsak közleményeiből vagy mások elbeszéléseiből, hanem személyesen is megismerhettem. Vele való találkozásomat a véletlennek köszönhetem. 1966 tavaszán Hannoverben, ahol akkor fiatal tudományos kutatóként dolgoztam, szinte az utolsó pillanatban értesültem arról, hogy a stresszelmélet atyja, a világhírü, nagy Selye professzor a Német Élettani Társaság (Deutsche Physiologische Gesellschaft) vendégeként annak speciális esti ülésének egyedüli előadója lesz. Rohanva érkeztem az egyetem már zsúfolásig megtelt nagytermébe, ahol szerencsémre az utolsó sor mögött még egy állóhelyet sikerült találnom. Innen hallgattam elbúvölve már folyamatban levő előadását és csodálhattam mesterien komponált vetített ábráit. Ez volt az első alkalom, hogy Selye professzort láttam, hallgattam, és meggyőződhettem arról, hogy ő nemcsak egy kimagaslóan nagy tudós, hanem egy szinte mágikusan effektív kommunikátor is. Ezt a nézetemet nyilvánvalóan az őt lelkesen ünneplő hallgatóság is osztotta, mivel alig hangzott el előadásának utolsó szava, valósággal megrohamozták ôt. Vele akartak beszélni és kezet fogni. Természetesen ez volt az én szándékom is. Csakhogy az amfiteátrum utolsó sorából a tömegen keresztül lejutni hozzá, szinte reménytelennek látszott. Mégsem adtam fel, s némi küzdelem árán, szándékom végül is megvalósíthatónak bizonyult. Mire azonban odaértem, ott egy hatalmas tömeg közepén találtam vagy inkább csak sejtettem Selye professzort. Miután csodával határosan sikerült a körülötte kialakult tömör embergyưrüt áttörnöm, bemutatkoztam neki. Hannoverben lévén, természetesen németül. Nevem és összetéveszthetetlen magyar akcentusom hallatán Selye professzor rögvest magyarul kezdett beszélni velem. Arra, hogy rövid, legfeljebb 2-3 perces beszélgetésünk során pontosan miről beszéltünk, már nem is emlékszem. Arra viszont egész pontosan, hogy amikor befejezésül megkérdezett, volna-e kedvem egy évig montreali intézetében vendégkutatóként dolgozni, azt feleltem: Professzor úr, ha kellene, még oda is úsznék! Mielőtt következő, már türelmetlenül várakozó tisztelőjéhez fordult volna, nekem adta névjegyét és arra bátorított, hogy írjak neki. Ezt én késlekedés nélkül meg is tettem. Így 1966. november 1-jén megkezdhettem az egy évet intézetében, amely valahogy nem fejeződött be 1970. szeptember 30-ig.

Röviddel Montrealba érkezésem után abban a nagy megtiszteltetésben volt részem, hogy Selye professzor bevett saját munkacsoportjába, amely akkor a plurikauzális betegségek koncepcióján intenzíven dolgozott. Számomra nagyon érdekesnek tûnt, hogy bizonyos kémiai vagy fizikai ágensek, amelyek egyedül semmiféle észlelhető biológiai hatást nem fejtenek ki, bizonyos sorés időbeli kombinációban alkalmazva viszont specifikus elváltozásokhoz vezetnek. Ezért nagy érdeklődéssel és szorgalommal törekedtem mielőbb a csoport által végzett kísérletekbe aktívan bekapcsolódni. Ily módon sikerült hamarosan az intézetben folyó kutatási témákba némi betekintést nyernem és bizonyos gyakorlati ismeretekre is szert tennem. Ez a kvázi crash-course lehetővé tette számomra, hogy lépésről lépésre a Selye-csoport hasznos tagjává válhassak. Egy nagyobb közlemény publikációra való előkészítését követően, amelyben intézetében először szerepeltem társszerzóként, Selye profeszszor javasolta, hogy maradjak továbbra is intézetében az eredetileg egy évre tervezett perióduson túl [3]. Egyben azt tanácsolta, hogy iratkozzam be a Montreali Egyetem orvosi fakultásának a PhD-fokozat megszerzéséhez szüikséges doktori iskola programjába. Az ezt követő években - amellett, hogy nagy intenzitással PhD-témámon dolgoztam - részt vehettem az intézet számos aktuális kutatási projektjében is $[4,5,6,7,8,9]$. Ez nemcsak egy lehetőség volt, hanem csakhamar meghatározott feladatommá is vált. Selye professzor ugyanis rám bízta az intézet kísérleteinek, s így a kórbonctani és kórszövettani kiértékeléseknek a koordinálását. Ez egy rendkívül széles körü feladatot jelentett, amely a stresszkutatást $[10,11]$ és a plurikauzális betegségek $[12,13]$ koncepciójának keretében folytatott sokoldalú állatkísérletek tervezésére, végrehajtására és interpretálására is kiterjedt. (Ennek egy nem lényegtelen aspektusa volt, hogy ezért a szolgáltatásért ösztöndíjamhoz egy szerény, de akkor nagyon jelentősnek érzett pótlékot is kaptam.)

Ez az említett két nagy átfogó téma magába foglalja azokat a megfigyeléseket, felfedezéseket és elméleteket, amelyek Selye életmúvének súlypontját képzik, s amelyek kreativitásának és eredetiségének tanúbizonyságai, konkrét megtestesítői. Továbbá azokat az állatkísérletekben kifejlesztett betegségmodelljeit is, amelyek az elmúlt évtizedek során kórfejlődéstani vizsgálatokban és farmakotoxikológiai interakciók tanulmányozására számos más intézményben máig is alkalmazásra kerülnek. Idetartoznak természetesen a Selye által kidolgozott kísérleti sebészeti technikák is.

A közelmúltban részletesen foglalkoztunk Selye János életmúvének néhány fontos fejezetével [14]. Ezért itt 
csak életpályájának kreativitásával és eredetiségével kapcsolatos vonásainak ismertetésére szorítkozom. Annál is inkább, mivel Selye életmúvét számos szerző korábban és részletesen méltatta $[15,16,17,18,19]$.

\section{Selye tudományos életpályája és világhírü intézetének felépítése}

Szokatlanul fiatalon, 21 éves korában, még mint a prágai német nyelvü egyetem orvostanhallgatója, jelent meg első közleménye [20]. Pályája kezdetén, főképpen német nyelven, érdekes esetek és megfigyelések leírására és közlésére fordította figyelmét.

Élete talán legfontosabb (79. számú) közleményét, amely Selyét elsőként tette világhírüvé, s amely egyáltalán a stresszkutatás kiindulópontjának tekinthető, 29 éves korában, 1936-ban publikálta [21]. Kreatívok és eredetiek voltak továbbá a harmincas évek második és a negyvenes évek első felében végzett munkái a szteroidok klasszifikációjáról, valamint élettani és gyógyszertani hatásukról [18, 22, 23, 24].

Kutatásainak és további tudományos kibontakozásának lehetőségei ugrásszerúen megnőttek 1945-ben. Ebben az évben, amikor 38 évesen, a montreali francia nyelvű Université de Montréal orvosi fakultásán Selye Jánost, az ugyancsak montreali angol nyelvú McGill University akkori szövettanprofesszorát az újonnan megalapított Institut de médecine et de chirurgie expérimentales egyetemi tanárává és első, s mint ma tudjuk, sajnos utolsó, igazgatójává nevezték ki. Az új intézet létrehozásával az egyetem vezetői egy, az orvostudomány széles skáláját átívelő alapkutatás és képzés céljára kívántak egy központi létesítményt megteremteni. Itt nyílt meg Selye számára az a nagy lehetőség, amely egyben élete nagy kihívása is volt, hogy saját elképzelése szerint egy világszínvonalú modern intézményt építhessen fel [25].

A kihívást Selye örömmel és tettre készen vállalta. Az egyetem fópeületének egyik szárnyában rendelkezésére bocsátott két teljes, de gyakorlatilag üres emeletén, a gyors berendezkedést követően hamarosan, szinte repülőstarttal megindulhatott Selye dinamikus vezetése alatt a produktív kutató- és oktatómunka. Ezt látszik bizonyítani Selye publikációi számának összehasonlítása az 1944 és 1946 közötti időszakból is. Közleményei számának 10-re (1945-ben) csökkenése, összehasonlítva 18-cal (1944-ben), illetve 15-tel (1946-ban), alig árulja el, hogy 1945 a költözködés, berendezkedés és megindulás éve volt [25].

$\mathrm{Az}$ intézet, rendeltetésének megfelelően, a kutatás mellett, illetve ezen belül a képzés, kizárólag a posztgraduális képzés Mekkája lett. Selye hírneve nyomán az évek során százak érkeztek a világ minden részéből intézetébe, hogy ott MSc vagy, ideális esetben, PhD-fokozatot szerezzenek, vagy pedig hosszabb-rövidebb ideig vendégkutatóként az intézet munkájában való részvételükből profitálhassanak (1.és 2. táblázat). A fiatal intézetnek
1. táblázat $\mid A z$ intézet munkatársainak és posztgraduális $(\mathrm{MSc} / \mathrm{PhD})$ hallgatóinak származási országai

\begin{tabular}{lll}
\hline 1. Argentína & 11. Haiti & 22. Németország \\
2. Ausztria & 12. India & 23. Olaszország \\
3. Belgium & 13. Indonézia & 24. Peru \\
4. Brazília & 14. Írország & 25. Portugália \\
5. Chile & 15. Japán & 26. Spanyolország \\
6. Csehszlovákia & 16. Jugoszlávia & 27. Svájc \\
7. Egyesült & 17. Kanada & 28. Svédország \\
\multicolumn{1}{c}{ Királyság } & 18. Korea & 29. Szovjetunió \\
8. Egyiptom & 19. Lengyelország & 30. Törökország \\
9. Franciaország & 20. Magyarország & 31. Uruguay \\
10. Görögország & 21. Mexikó & 32. USA \\
\hline
\end{tabular}

kezdetben nem állt megfelelő számú és Selye igényének megfelelő tudományos minősítésű, képzésre alkalmas személyzet rendelkezésére. Ezért, kreativitását ismét bebizonyítva, Selye létrehozta a Claude Bernard Visiting Professorship intézményét. Ezáltal sikerült neki világviszonylatban kiemelkedő tudósokat (köztük több Nobeldíjast) intézetébe hozni (1. ábra). Ott töltött néhány napos vendégeskedésük alatt a Claude Bernard-profeszszorok előadásaikkal és posztgraduális hallgatókkal folytatott beszélgetéseik révén hozzájárultak, Selye odaadó tanítómunkáját támogatva és kiegészítve, az intézet magas színvonalú képzéséhez.

Az intézet profiljának kialakításához és hatékony müködtetéséhez Selyének tudományos talentuma mellett egy másik képességére, legendás szervezôkészségére is szüksége volt.

$\mathrm{Az}$ általa megteremtett struktúra ideálisan szolgálta az intézetben folyó sokoldalú tematikájú kutatás igényeit. Specializált osztályok (például biokémiai, hisztokémiai, szövettani, elektronmikroszkópiai, állatkísérleti, dokumentációs könyvtár stb.) segítették a kutatókat abban, hogy rutin technikai részletkérdések helyett munkájuk tudományos aspektusaira koncentrálhassanak.

Selye életmúvének, különösen kreativitásának és eredetiségének méltatása és megértése elképzelhetetlen lenne, ha egy további, rá tipikusan jellemzô és meghatározó tulajdonságát, fenomenális kommunikációs képességét figyelmen kívül hagynánk. Ez utóbbi kétségtelenül lényegesen hozzájárult széles körü ismertségéhez és népszerüségéhez. A világhírü kutató, Selye János, kilépett a tudósok képzeletbeli elefántcsonttornyából, vagy ha úgy tetszik, tágra nyitotta ennek kapuit a társadalom széles szegmentjeinek érdeklődői számára. Briliáns, többnyire angolul, franciául, németül vagy magyarul tartott előadásai, az ezeket kísérő informatív és magas fokú profeszszionalitással elkészített illusztrációi, maradandó benyomást keltettek és hagytak hátra hallgatóiban. Nemcsak tudósok vagy más szakemberek, hanem laikusok is lenyűgözve hallgatták előadásait, és elragadtatva olvasták 
2. táblázat |Az intézet publikációs nyelvei (gyakorisági sorrendben)

\begin{tabular}{lll}
\hline 1. Angol & 7. Japán & 13. Román \\
2. Francia & 8. Lengyel & 14. Szerb-horvát \\
3. Német & 9. Koreai & 15. Interlingua \\
4. Olasz & 10. Orosz & 16. Svéd \\
5. Spanyol & 11. Portugál & 17. Szlovák \\
6. Magyar & 12. Cseh & \\
\hline
\end{tabular}

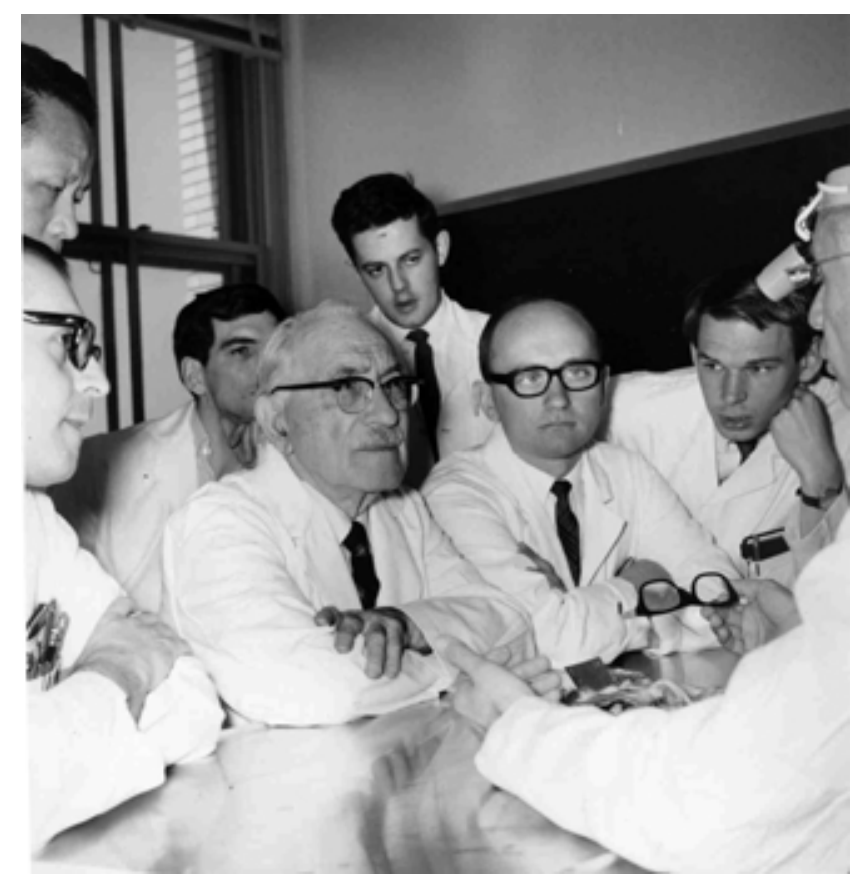

1. ábra

Selye János intézete, egy „kisméretű Egyesült Nemzetek Szövetsége”. Balról jobbra: Giulio Gabbiani, Ung Soo Pahk, Gaston Coté, Selman A. Wachsman (Claude Bernard-vendégprofesszor, 1952-es Nobel-díjas), Laurent Savoie, Somogyi Árpád, Wilhelm Scholz, Selye János, 1967

közérthetően fogalmazott írásait. Mivel több, eredetileg angol nyelven írt könyvét más nyelvekre, többek között magyarra is lefordították, így olvasóinak tábora feltehetően több százezres, talán milliós nagyságrendre is bővülhetett. Körültekintő magatartásának fontos jellemzője volt, amellyel joggal büszkélkedett, hogy előadásai során ő a mindenkori hallgatósága feltételezhető ismeretszintjéhez szigorúan igazodott. Így például a stresszről tudott úgy előadni, hogy laikus hallgatói gondolatait megérteni és követni tudták. Másrészt viszont tudósok körében úgy beszélt, hogy hallgatói ne tartsák előadását sértően alacsony nívójúnak. Fáradhatatlanul biztatta tanítványait, ebben a vonatkozásban is, példájának követésére. Selye professzor hitelességét, előadásainak a hallgatóságra gyakorolt lenyűgöző hatását a következő anekdota találóan jellemzi: 1976-ban berlini intézetünk (Bundesgesundheitsamt) centenáris rendezvényének díszvendégeként és ünnepi szónokaként, ahogy tóle megszokott, egy nagy sikerú beszédet tartott. Ennek befejeztével az akkori német egészségügyi miniszter odalépett hozzá, hogy gratuláljon és megjegyezte: Professzor Úr, előadásának olyan nagy meggyőző ereje volt, hogy ha én most megkérdezném, hogy lehet a rákot gyógyítani, Ön egy szempillantás alatt azt is megmondaná.

Selye mindenekfelett kitúnő tanítómester is volt, aki nagy szenvedéllyel tanított. Az intézet napi programjának szerves részeként rendszeresen találkozott munkatársaival, akiket az intézet aktuális kutatási témáinak megbeszélése és boncolások elvégzése közben, példájával, gondolataival, bírálatával és, időnként, elismerésével is tanított. Selye természeténél fogva perfekcionista volt. Az erre való törekvést munkatársaitól is elvárta, sőt megkövetelte. Betartását a mindennapok gyakorlatában figyelemmel kísérte és, ha szükségesnek látta, beavatkozott. Az intézet jó hírnevére féltóen ügyelve, tervezett házon kívüli szereplések (például konferenciák) előtt, különösen fiatal munkatársaitól megkövetelte, hogy az intézetben próbaelöadást tartsanak. Az ezt követő próba kérdés-felelet könnyen kínos élménnyé mutálhatott.

Perfekcionizmusával együtt járt Selye hatalmas munkabíró képessége. Azoknak, akik huzamosabb ideig szándékoztak vele dolgozni és föképpen, ha a PhD-program kutatási hányadát intézetében eredményesen lezárni reméltek, sok más feltétel teljesítése mellett, magas álló- és alkalmazkodási képességgel kellett rendelkezniük. Azonban, mindenesetre, napi 10-12 óra, heti 7 nap és évi 365 nap idôbeli munkapenzumát magukévá kellett tenni.

Akármivel is foglalkozott, azt ő teljes odaadással tette. Selye professzornál üresjárat nem volt! Egyetlen, talán mosolygásra késztető példa napi rutinjából mutatja, hogy mennyire racionálisan tudott hellyel és idejével gazdálkodni: Egy, az egyetem napsütötte déli oldalán fekvő, Floridának elnevezett helyiségben, amely tulajdonképpen az általa írt könyvek raktára volt, nyitott ablaknál (a montreali zord télben hideg ellen hősugárzókkal védve), egy függóágyban fekve szokott ebédelni, napozni és napi postáját (20-30 levél) hangrögzítőre diktálva megválaszolni. (Ezért ő mindig, még a tél közepén is, floridai napbarnított volt.)

Selye egy rendkívül termékeny szerzố is volt. Közleményeinek magas száma (1700 felett) magáért beszél. Azok a témakörök, amelyek életmúvének tudományos tartamát képzik, korábbi méltatások tárgyai voltak. Ezért itt csupán Selye eredetiségének és kreativitásának egy további megnyilvánulása kerül említésre. Sokkal a ma használatos internetes keresők (search engines) felfedezése és alkalmazása előtt, 1956-ban Selye leírt, később továbbfejlesztett és kifinomított egy általa symbolic shorthand systemnek (SSS) elnevezett rendszert [26]. Ennek segítségével irodalmi források felkutatása, az akkor rendelkezésre álló egyéb módszerekhez képest, lényeges előrehaladást jelentett. Az SSS és intézetének ugyancsak általa felépített legendás dokumentációs rendszere tette számára lehetségessé, hogy az ő kreativitásával megteremtett, általa bevezetett analytico-synthetic-style alkalma- 
zásával több monográfiáját ezért különösen nagy hatékonysággal tudta megírni. Ezek a nagy gonddal megtervezett, előkészített, megírt és szerkesztett múvek már röviddel megjelenésüket követően a megfelelő tudományterületek átfogó és rendkívül nagyra becsült enciklopédiáivá váltak. Használóik biztosak lehettek abban, hogy a kézirat nyomdába adásának napjáig megjelent releváns forrásmunkák nem hiányoztak Selye könyveinek irodalomjegyzékéból [11, 24, 27, 28, 29, 30].

\section{Selye a kreativitás, eredetiség és a kommunikáció nagymestere}

A tudomány történelme ellentmondásokkal, vitákkal, gyakran éles vitákkal van tele. Bizonyos szarkazmussal mondhatnánk, hogy a vita élességének intenzitása egyenes arányban áll a mindenkori, valóban eredeti felfedezés jelentőségével. Mint sok más kreatív és eredeti tudósnak, akik a kor szellemével konform gondolatvilágból, éppen egyéniségükből fakadóan, ki akarnak törni, Selyének is sok csatát kellett megvívnia, hogy igazát bebizonyítsa és érdemre juttathassa. Ezekről ő sokat írt, és akik hosszú időn át vele dolgoztak, tudják, hogy még annál is többet beszélt [31].

Selye felfedezései felett vívott régmúlt verbális csatákról manapság lamentálni anakronizmus lenne. Őt már rég nem kell megvédeni. Ezrekre tehető, a világ legjobb tudományos folyóirataiban megjelent közleményei és a világ legjobb kiadói által megjelentetett könyvei, munkáinak széles körű elismerése, életművének meggyőző tanúbizonysága, amely mellett kritikusai eltörpültek. Munkáit százezres nagyságrendben citálták. [32]. Nobel-díjra való tízszeres jelölése, negyvenen felüli honoris causa doktorátusa, számos más jellegű, magas rangú kitüntetése egyértelmúen bizonyítja jelentőségét.

Selye korán meginduló, több mint fél évszázados tudományos pályáján különlegesen nagy tehetséggel, imponáló állhatatossággal és szinte kimeríthetetlen energiával, kreatív, eredeti és kommunikatív lényével ritkán látott sikereket ért el. Ezért világszerte elismerést, tiszteletet, sőt csodálatot is vívott ki. Igen, ő valóban a kreativitás, eredetiség és - tegyük hozzá - a kommunikáció nagymestere is volt. Kissé patetikusan fogalmazva: egész életét a tudománynak szentelte. Racionálisan fogalmazva, multitalentumát, sokrétű adottságát önmegvalósítására, netán a több mint megérdemelt Nobel-díj elnyerésére fordította? Ez az ő titka volt, és, a sok találgatás dacára, az ő titka is maradt. De ez lényegtelen. Ami fontos, az az, hogy egy nagyon nagy szellemi örökséget hagyott hátra a világra, számunkra, amely fiatal kutatók generációit a jövőben is lelkesíteni és motiválni fogja, hogy erre az örökségre építve tovább kutassanak, és olyan szellemi javakat hozzanak létre, amelyekre ő büszke lenne. Selye János egy rendkívül múvelt, magas intelligenciájú, fegyelmezett, keményen, rendkívül nagy hatékonysággal és racionalitással dolgozó, inspiráló kutató, tanár, filozófus, író és briliáns előadó volt.

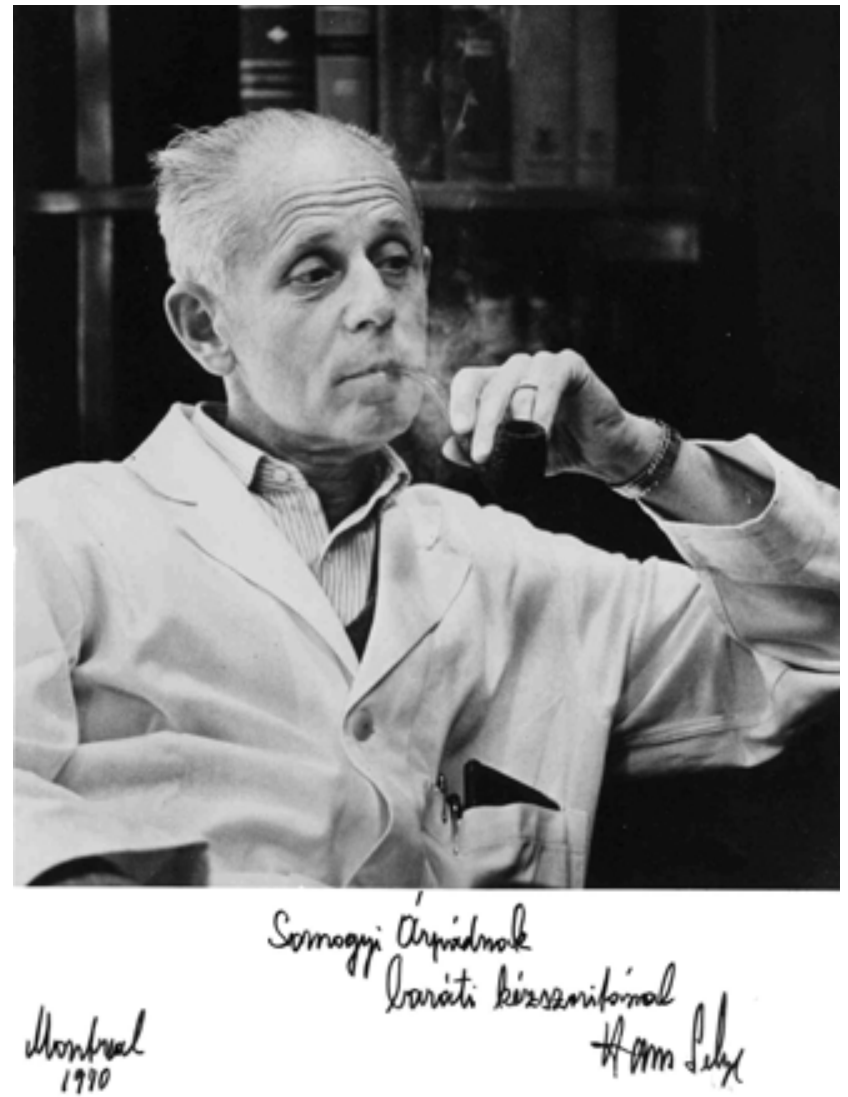

2. ábra | Prof. Dr. Selye János fotója, a szerzőnek szóló dedikációval

Selye professzortól, a XX. század tudományának egyik óriásától tanulni, az általa megteremtett, stimulálóan intellektuális és kompetitív légkörben vele dolgozni talán életem legnagyobb privilégiuma volt (2. ábra). Az intézetében 1966 és 1970 között eltöltött négy év későbbi - kutatói, egyetemi tanári, valamint nemzeti és nemzetközi szabályzó intézmények és testületek vezetői - életpályámra egyaránt rányomta bélyegét. Szakmailag és emberileg sokat profitáltam és még ma is profitálok abból, amit tóle tanultam. Megtanított arra, hogy miként kell adekvát vizsgálatokat tervezni, végrehajtani és eredményeit értékelni. Ennek, tudományos értékén túl, nagy gyakorlati jelentősége is van. Különösen olyan helyzetekben, amelyekben a közösséget fenyegető veszély elleni védelemre és elhárítására hivatott intézményeknek, a vizsgálatok eredménye alapján konkrét döntéseket kell, itt és most, tenniük. De talán a legfontosabb, amit Selye professzortól tanultam, az a tudomány müvelésének szenvedélye és szeretete volt.

Sajnálatos módon intézete, az Institut de médecine et de chirurgie expérimentales, amelyet ő alapított és tett világhírúvé, nem élhette túl megteremtőjét.

Anyagi támogatás: A közlemény megírása anyagi támogatásban nem részesült. 
A szerző a cikk végleges változatát elolvasta és jóváhagyta.

Érdekeltségek: A szerzőnek nincsenek érdekeltségei.

\section{Irodalom}

[1] Fodor, L.: The creative personality. [A kreatív személyiség.] Közoktatás, 2007, 18(7), 4-6. [Hungarian]

[2] Szent-Györgyi, A.: Foreword. In: Selye, H.: In Vivo. The case for supramolecular biology. Liveright Publishing Corporation, New York, 1967.

[3] Selye, H., Somogyi, A., Vegh, P.: Inflammation, topical stress and the concept of pluricausal diseases. Biochem. Pharmacol., 1968, 17(Suppl. 1), 107-122.

[4] Selye, H., Pabk, U. S., Somogyi, A.: Prevention of renal necrosis by stress. JAMA, 1967, 201(13), 1026-1029.

[5] Selye, H., Somogyi, A, Mécs, I.: Calcergy inhibited by calciphylactic challengers. Science, 1968, 159(3821), 1361-1362.

[6] Selye, H., Somogyi, A., Côté, G.: Sensitization by corn oil for the production of cardiac necroses by various steroids and sodium salts. Am. J. Cardiol., 1968, 23(5), 719-722.

[7] Somogyi, A., Selye, H.: Tourniquet poditis - an experimental pedal inflammation in the rat. Arzneimittelforschung, 1969, 19(6), 977-981

[8] Somogyi, A., Berczi, I., Selye, H.: Inhibition by salicylates of various calcifying connective-tissue reactions. Arch. Int. Pharmacodyn. Ther., 1969, 177(1), 211-223.

[9] Somogyi, A., Kovacs, K., Selye, H.: Jejunal ulcers produced by indomethacin. J. Pharm. Pharmacol., 1969, 21(2), 122-123.

[10] Selye, H.: Stress. ACTA, Inc., Medical Publishers, Montreal, 1950.

[11] Selye, H.: Stress in health and disease. Butterworth, Boston, 1976.

[12] Selye, H.: Pluricausal diseases. Exp. Med. Surg., 1966, 24(2), 191-209.

[13] Selye, J., Somogyi, A., Végh, P.: Inflammation and stress in the light of the concept of pluricausal diseases. [Gyulladás és stress a pluricausalis betegségek koncepciójának megvilágításában.] Orv. Hetil., 1967, 108(52), 2449-2456. [Hungarian]

[14] Szabo, S., Tache, Y., Somogyi, A.: The legacy of Hans Selye and the origins of stress research: A retrospective 75 years after his landmark brief "Letter" to the Editor of Nature. Stress, 2012, 15(5), $472-478$.

[15] Szabó, S.: Half a century of stress research: a tribute to Hans Selye by his students and associates. Experientia, 1985, 41(5), 559578
[16] Szabo, S.: The creative and productive life of Hans Selye: A review of his major scientific discoveries. Experientia, 1985, 41(5), 564567.

[17] Taché, Y.: A tribute to the pioneering contributions of Hans Selye: an appraisal through his books. Experientia, 1985, 41(5), 567-568.

[18] Szabo, S.: Hans Selye 70 years later: Steroids, stress ulcers \& H. pylori. [Selye János 70 évvel később: szteroidok, stresszfekély és Helicobacter pylori.] Ideggyogy. Sz., 2014, 67(3-4), 91-94.

[19] Gabbiani, G.: Reflections on biological research. Warren $\mathrm{H}$ Green, Inc., St. Louis, 1967.

[20] Selye, H.: On two noteworthy cases of carcinosarcoma. [Über zwei bemerkenswerte Fälle von Karzinosarkom.] Med. Klin., 1928, 24, 1197. [German]

[21] Selye, H.: A syndrome produced by diverse nocuous agents. Nature, 1936, 138, 32.

[22] Selye, H.: Pharmacological classification of steroid hormones. Nature, 1941, 148, 84-85.

[23] Selye, H.: An attempt at a natural classification of the steroids. Nature, 1943, 151, 662-663.

[24] Selye, H.: Hormones and resistance. Springer Verlag, New York, 1971

[25] N. N.: Blue book. Institute of Experimental Medicine and Surgery. University of Montreal, 1970.

[26] Selye, H., Nádasdi, M.: Symbolic shorthand system (SSS) for physiology and medicine. Published by the Institut de médecine et de chirurgie expérimentales, Université de Montréal. 2nd ed. Montréal, 1958.

[27] Selye, H.: The mast cells. Butterworth, Washington, 1965.

[28] Selye, H.: Thrombohemorrhagic phenomena. C. C. Thomas Publ., Springfield, 1966.

[29] Selye, H.: Anaphylactoid edema. Warren Green, St. Louis, 1968.

[30] Selye, H.: Experimental cardiovascular diseases. Springer Verlag, New York, 1970.

[31] Selye, H.: In Vivo. The case for supramolecular biology. Liveright Publishing Corporation, New York, 1967

[32] Selye, H.: Health and the stress concept. In: Fülgraff, G. (ed.): Health risks. [Gesundheit und Streß-Koncept. In: Fülgraff, G. (Hrsg.): Risiken für die Gesundheit.] Gustav Fischer Verlag, Stuttgart-New York, 1976. [German]

(Somogyi Árpád dr., D-12309 Berlin, Töpchiner Weg 163. e-mail: arpad_somogyi@yahoo.co.uk) 